African Crop Science Journal by African Crop Science Society is licensed under a Creative Commons Attribution 3.0 Uganda License. Based on a work at www.ajol.info/ and www.bioline.org.br/cs DOI: https://dx.doi.org/10.4314/acsj.v27i4.5

\title{
OPTIMISATION OF YAM SEED-TUBER PRODUCTION BY VINE CUTTINGS PROPAGATION
}

\author{
I.K. FOFANA, Y.C. BROU, E.O. TIENEBO, D.C. AKMEL ${ }^{1}$, E.L. WOGNIN ${ }^{2}$ and K.A. TOURE
}

National Polytechnic Institute - Felix Houphouet-Boigny (INP-HB), Department of Agriculture and Animal Resources, P. O. Box 1313 Yamoussoukro, Cote d'Ivoire

${ }^{1}$ Department of Chemical Engineering and food Industry. P. O. Box 1093 Yamoussoukro, Côte d'Ivoire

${ }^{2}$ Department of Electrical and Electronic Engineering. P. O. Box 1093 Yamoussoukro, Côte d'Ivoire ${ }^{3}$ Department of Mathematics and Informatics. P. O. Box 1093, Yamoussoukro, Côte d'Ivoire

Corresponding author: fik.1957a@gmail.com

(Received 10 November 2018; accepted 30 October 2019)

\begin{abstract}
In Côte d'Ivoire, yam (Dioscorea alata L.) is the most important food crop, with 5.8 to 6 million tonnes of tubers produced over an area of 876,540 to 1 million ha from 2014 to 2018. Despite this performance, cropping practices have remained traditional. Part of the previous year's harvest is diverted to be used as planting material for the current year. In response to this constraint, aerial stem cuttings appear to be an alternative method to obtain mini-seed tubers. This study aimed at optimising and standardising the technique for producing yam seed-tubers of the alata species, using cuttings from the aerial stems of two Ivorian varieties; namely Bètè-bètè and Florido. The study was carried out at the farm of the National Polytechnic Institute Félix Houphouet Boigny of Yamoussoukro (central region of Côte d'Ivoire). A Fractional Factorial Plan trial was therefore set up to assess 5 factors: the substrate, the sampling level and stage of the stem cuttings, coconut water and urea. The survival rate of stem cuttings and the weight of the minitubers obtained were measured. Results on the survival rate of var. Bètè-bètè reveal that this rate depends firstly on the sampling stage, then on the sampling level and finally on the interaction substrate $\mathrm{x}$ sampling stage. In var. Florido, the sampling stage had the greatest influence on survival rate, followed by the substrate and interaction substrate $\mathrm{x}$ sampling level. The interaction substrate $\mathrm{x}$ sampling stage has the greatest influence on the weight of the minitubers, followed by urea and then coconut water invar. Bètè-bètè. In var. Florido, the sampling stage is the most influential, followed by the interaction substrate $\mathrm{x}$ urea and finally coconut water and urea.
\end{abstract}

Key Words: Côte d'Ivoire, cuttings propagation, Dioscorea alata 
En Côte d'Ivoire, l'igname occupe le premier rang des productions vivrières avec 5,8 millions de tonnes depuis 2014 sur une superficie de 876540 ha. Malgré cette performance, les techniques culturales sont restées traditionnelles. Une partie de la récolte de l'année précédente est détournée pour servir de matériel de plantation de l'année en cours. Face à cette contrainte, le bouturage des tiges aériennes apparaît comme une méthode alternative pour obtenir des mini-tubercules semences. La présente étude vise l'optimisation de cette technique de production de tubercules-semences chez 2 variétés locales d'igname, Bètè-bètè et Florido, de l'espèce Dioscorea alata. Un essai en Plan Factoriel Fractionné a donc été mis en place portant sur 5 facteurs: le substrat, le niveau et le stade de prélèvement des boutures-tiges, l'eau de coco et l'urée. Le taux de survie des boutures-tiges et le poids des minitubercules obtenus ont été évalués. Les résultats sur le taux de survie de la var. Bètè-bètè révèlent que ce taux dépend plus du stade de prélèvement, ensuite du niveau de prélèvement et enfin de l'interaction substrat x stade de prélèvement. Chez la var. Florido, le stade de prélèvement influence plus le taux de survie, suivi du substrat et de l'interaction substrat $\mathrm{x}$ niveau de prélèvement. L'interaction substrat $\mathrm{x}$ stade de prélèvement influence plus le poids des mini-tubercules, suivie de l'urée puis de l'eau de coco chez la var. Bètè-bètè. Chez la var. Florido, le stade de prélèvement a plus d'impact, suivi de l'interaction substrat $x$ urée et enfin l'eau de coco et l'urée.

Mots Clés: Côte d'Ivoire, cuttings propagation, Dioscorea alata

\section{INTRODUCTION}

In Côte d'Ivoire, yam (Dioscorea alata L.) is one of the staple food crop with a production of about 6 million metric tonnes of tubers over an acreage of about one million ha (FAOSTAT, 2017). The central part of the country, a traditional agroecological zone of this crop accounts for $60 \%$ of national production (Sylla, 2009).

In almost all yam cropping systems, seeds for the following planting season are taken directly from the current harvest. This practice sometimes represents a significant proportion of consumption (20-30\%), notably for large families (Foua-Bi, 1993; Hinvi and Nonfon, 2000; Dansi, 2003). Such situation keeps populations in food and financial precariousness over generations, which is of particular concern as they are sometimes forced to purchase yam tubers for the following year's planting. Besides, these conventional seed-tubers are often vectors of parasites such as nematodes and microbial pathogens (Coyne et al., 2006). Moreover, due to the climate change, these tubers may be entirely lost once sown, when there is not enough moisture for sprouting and development of aerial stems. Therefore, without any residual seed-tubers, growers cannot replace dead seedlings (Ayankanmi $e t$ al., 2005). Alternative yam cropping methods are then required. A promising technique resides in producing mintubers from aerial stems (Buffard-Morel and Toure, 1980). In its early approaches, this technology aimed to produce immediately edible yam tubers directly (Akoroda and Okonmah, 1982). But these attempts did not achieve the final objective of producing tubers in abundance and on a large scale. Researches carried out by IITA in Ibadan, Nigeria in the early 2000s, based on the use of yam stem fragments sown on sterile substrates, had resulted in tubers of varying size as seeds (Komaki et al., 2002; Shiwachi et al., 2005). Some of these researches used synthetic and natural hormones to improve the yield and the weight of mini-tubers (Agele $e t$ al., 2010).In Cote d'Ivoire, our researches were focused on different techniques ensuring a better recovery to transplanted stem cuttings. Unfortunately, the expected goals were not 
achieved (Dibi et al., 2014). Indeed, at the end of our tests, the number and average weight of mini tubers were 1.73 and $36.63 \mathrm{~g}$ for variety $\mathrm{C} 18$ and 1.03 and $4.35 \mathrm{~g}$ for variety Kponan. We considered that these values are low a priori. One of the reasons for this inadequacy is that the optimisation of the technique's protocols has not yet been considered, particularly regarding the control of the key factors that influence and maximise this production. Most studies on the issue have so far been conducted in a sectoral manner, each often addressing a very few number of parameters (Komaki et al., 2002; Acha et al., 2004; Shiwachi et al., 2005), and with no regard to interaction effects (Acha et al., 2004; Behera et al., 2009a). Thus, for example, the effect of coconut water at different doses was studied independently of the substrate used and the sampling stage. One wonders what the contribution of each factor is to the studied parameters.

The present study focuses on the optimisation of the production technique of seed tubers from aerial yam stems, which either will be sown according to conventional cropping systems (for those weighing over 70 g) or will undergo a nursery stage (for those weighing less than $70 \mathrm{~g}$ ) in Yamoussoukro (central Côte d'Ivoire).

\section{MATERIALS AND METHODS}

Plant materials. Two yam varieties of the alata species, locally known as Bètè-bètè and Florido, were grown to produce stem-cuttings (Fig. 1).

Five factors, each with two levels, were studied: the substrate $\mathrm{x}_{1}$ (carbonised rice husk or humus soil), the sampling level of the cuttings on the mother stem $\mathrm{x}_{2}$ (median cuttings and terminal cuttings), the sampling stage of the stem cuttings $\mathrm{x}_{3}$ (90 or 120 days after sowing (das), coconut water $\mathrm{x}_{4}(5 \%$ or $10 \%)$ and urea $\mathrm{x}_{5}(2 \%$ or $3 \%)$. The experimental design was a fractional factorial plan which derived from the confounding of two interactions $\left(\mathrm{x}_{1} \mathrm{x}_{2}\right.$ and $\left.\mathrm{x}_{2} \mathrm{x}_{3}\right)$ of a complete factorial design. This type of experimental design is commonly used in industry where manufacturing processes or laboratory experiments are becoming more and more complex because they involve a large number of variables or factors (Feinberg, 1996; Jayaraman, 1999). This type of experimental design is different from the conventional designs used in agronomy such as randomised complete blocks, split-plot, etc. The confounding resulted in 8 elementary plots receiving different combinations of the levels of the factors (T1, T2, T3, T4, T4, T5, T6,

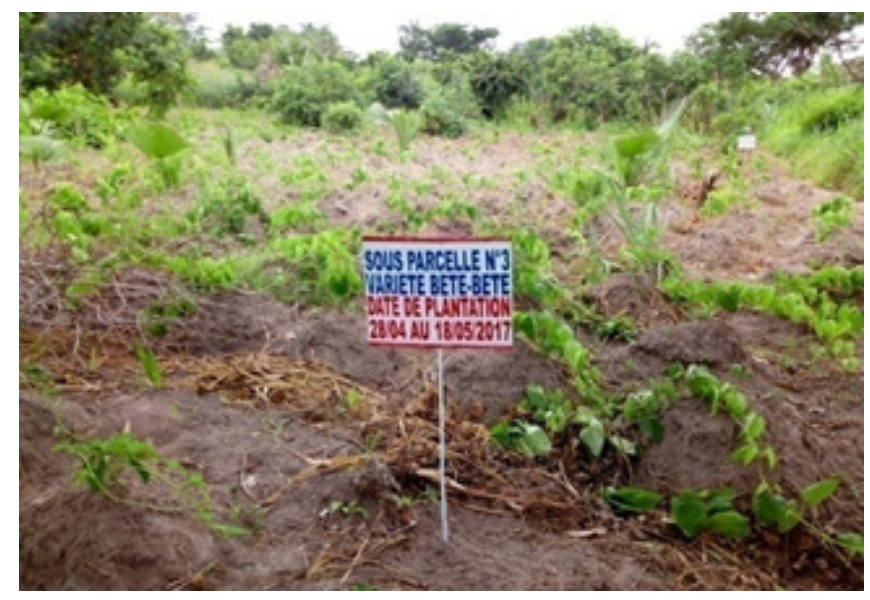

Figure 1. Variety Bètè-bètè stem-cutting production plot. 
T7, T8), two elementary control plots (T0S1, T0S2) and 3 elementary replicate plots (R1, $\mathrm{R} 2, \mathrm{R} 3)$ to calculate the experimental error (Table 1).

Trial implementation. Cuttings were excised 90 or 120 days after sowing on stalks stemmed from mounded tubers (Fig. 2).

The cuttings were soaked for $24 \mathrm{hr}$ into 5 or $10 \%$ of coconut water solutions. The seedbeds, which received the cuttings, were previously treated with a nematicide Vytal 5G (a.m. oxamyl $30 \mathrm{~g} \mathrm{~kg}^{-1}$ ) at a dose of $10 \mathrm{~g} \mathrm{~m}^{-2}$, applied only on the planting lines. The fungicide Ivory $80 \mathrm{WP}$ (a.m. mancozeb $800 \mathrm{~g} \mathrm{~kg}^{-1}$ ) was evenly distributed over the surface of the bed, at a dose of $50 \mathrm{gm}^{-2}$ diluted in $10 \mathrm{~L}$ of water. The stem-cuttings were transplanted into the selected substrates, i.e., carbonised rice husks mixed in equal volumes with the soil from the beds or the humus soil collected undergrowth also mixed in equal volume with the soil of the beds. The substrates were pre-treated 48 hours before with 2 or $3 \%$ of urea solution.

Measured parameters. The survival rate of the stem-cuttings was determined for each variety, forty days after planting according to the formula:

Stem cuttings survival rate $=$

Number of planted stem cuttings alive

Total number of stem cuttings planted 100

The mean weight of the mini-tubers was determined for each variety per plant using the formula below:

Minitubers weight $=$

Minitubers weight per seedbed Number of seed holes

The survival rate of the stem-cuttings was determined for each variety

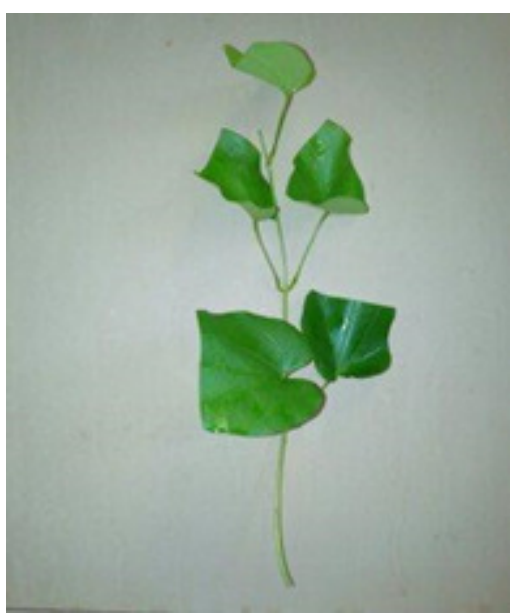

Figure 2. Excised stem cutting.

Statistical analysis. Coefficients of factor effects were computed according to Yates's method (Yates, 1935; Yates, 1978) by using the multiple regression method between the factors and each of the responses, at significance threshold $\alpha=0.05$. The significance of factors' effects was checked by two means; firstly, main and interaction effects were discriminated on Daniel's diagram. Main and interaction factors that have the greatest and significant effect depart from the Henry line displayed in green on Daniel's diagram. Secondly, the significance of the coefficients $\left(a_{i}\right)$ was confirmed by comparing them with the absolute value of the estimated experimental error (Se). When these coefficients were at least two times greater than this absolute value $\left(\left|a_{i}\right|>2 \times S e\right)$, they were kept in the model. In case the $\left|a_{i}\right|<2 \times$ Se but the dispersion of points from Henry's line points out that the corresponding factors have a significant effect, Morineau and Chatelin (2005) suggested to keep in the model as significant the absolute value of the coefficients $\left|a_{i}\right|>\operatorname{Se}$.

In the case of $\left|a_{i}\right|<S e$, the interpretation according to the dispersion from the Henry line will be retained only for main effects. The DESIGN-Expert software (Demo version 11) was used to finalise the optimisation of the 
TABLE 1. Experimental matrix of the fractional factorial design

\begin{tabular}{|c|c|c|c|c|c|c|}
\hline Organisation of the tests & Treatment & $\begin{array}{l}\text { Substrate } \\
X_{1}\end{array}$ & $\begin{array}{l}\text { Sampling level } \\
\mathrm{X}_{2}\end{array}$ & ampling stage & $\begin{array}{l}\text { Biostimulant } \\
\mathrm{X}_{4}\end{array}$ & $\begin{array}{l}\text { Fertiliser } \\
\mathrm{X}_{5}\end{array}$ \\
\hline & $\mathrm{T} 1$ & Humus soil & Median cutting & 120 das & Coconut water $5 \%$ & Urea $2 \%$ \\
\hline & $\mathrm{T} 2$ & Carbonised rice husk & Median cutting & 120 das & Coconut water $10 \%$ & Urea $2 \%$ \\
\hline & $\mathrm{T} 3$ & Humus soil & Terminal cutting & 120 das & Coconut water $10 \%$ & Urea $3 \%$ \\
\hline & $\mathrm{T} 4$ & Carbonised rice husk & Terminal cutting & 120 das & Coconut water $5 \%$ & Urea $3 \%$ \\
\hline & $\mathrm{T} 5$ & Humus soil & Median cutting & 90 das & Coconut water $5 \%$ & Urea $3 \%$ \\
\hline & T6 & Carbonised rice husk & Median cutting & 90 das & Coconut water $10 \%$ & Urea $3 \%$ \\
\hline & $\mathrm{T} 7$ & Humus soil & Terminal cutting & 90 das & Coconut water $10 \%$ & Urea $2 \%$ \\
\hline & $\mathrm{T} 8$ & Carbonised rice husk & Terminal cutting & 90 das & Coconut water $5 \%$ & Urea $2 \%$ \\
\hline & T0S1 & Carbonised rice husk & Cuttings in the upper $1 / 3$ & 105 das & None & None \\
\hline & TOS2 & Humus soil & Cuttings in the upper $1 / 3$ & 105 das & None & None \\
\hline \multirow[t]{4}{*}{ Repetitions for test validation } & $\mathrm{R} 1$ & Carbonised rice husk & Terminal cutting & 90 das & Coconut water $5 \%$ & Urea $2 \%$ \\
\hline & $\mathrm{R} 2$ & Carbonised rice husk & Terminal cutting & 90 das & Coconut water $5 \%$ & Urea $2 \%$ \\
\hline & $\mathrm{R} 3$ & Carbonised rice husk & Terminal cutting & 90 das & Coconut water $5 \%$ & Urea $2 \%$ \\
\hline & & $\mathrm{X}_{1}$ & $X_{2}$ & $\mathrm{X}_{3}$ & $\mathrm{X}_{4}$ & $X_{5}$ \\
\hline Level-1 & & Humus soil & Median cutting & 120 das & Coconut water $10 \%$ & Urea $3 \%$ \\
\hline Level +1 & & Carbonised rice husk & Terminal cutting & 90 das & Coconut water $5 \%$ & Urea $2 \%$ \\
\hline
\end{tabular}


results. The software calculates the main effects of each factor and the interactions between these factors by varying the values of all of them in parallel. This software computes several combinations between the factors' levels in order to retain the best optimisation responses ranked in decreasing order of importance (Plant, 2013).

\section{RESULTS}

Variety Bètè-bètè cuttings' survival rate. The computed coefficients of the effects of factors are presented in Table 2. The effects of the main and interaction effects were discriminated on Daniel diagram (Fig. 3). From Daniel diagram, the sampling stage $\left(\mathrm{x}_{3}\right)$ got the highest effect, even if it was negative; followed by the sampling level and the interaction effect of the substrate and the sampling stage. Survival rates' standard deviation was 20.81, resulting into an experimental error $(2 \times \mathrm{Se}=2 \times 20.81 / \sqrt{3})$ equalled to 24.03.Thus, it can be stated that only the effects of the sampling level $\left(\mathrm{x}_{2}\right)$, and the positive interaction between the substrate $\left(\mathrm{x}_{1}\right)$ and the sampling stage $\left(\mathrm{x}_{3}\right)$ are significant.

Variety Florido cuttings' survival rate. The computed coefficients of the effects of factors are presented in Table 3. The effects of the main and interaction factors were discriminated on Daniel diagram (Fig. 4) From Daniel diagram, the sampling stage $\left(\mathrm{x}_{3}\right)$ got the highest effect, even if it was negative; followed by the substrate $\left(x_{1}\right)$ factor and the interaction effect of the substrate and the sampling level. The standard deviation of the rates was 30.55 , resulting in the experimental error $2 \times \mathrm{Se}$ estimated to 35.27. Thus, it can be stated that only the effects of interaction between the substrate $\left(\mathrm{x}_{1}\right)$ and the sampling level $\left(\mathrm{x}_{3}\right)$ were significant.

Variety Bètè-bètè seed tuber production. The computed coefficients of the effects of factors are presented in Table 4 . The effects of the main and interaction factors were discriminated on Daniel diagram (Fig. 5). From Daniel diagram, interaction the substrate $\left(\mathrm{x}_{1}\right)$ and the sampling stage $\left(\mathrm{x}_{3}\right)$ got the highest effect, followed by the confounding effects of (Komaki et al., 2002; Shiwachi et al., 2005). fertiliser urea $\left(\mathrm{x}_{5}\right)$ and coconut water $\left(\mathrm{x}_{4}\right)$, respectively. The interaction effect of the substrate $\left(\mathrm{x}_{1}\right)$ and urea, and the main effect of the sampling level came in fourth and fifth positions, respectively; but had a negative impact on the Bètè-bètè seed-tuber production. Besides, the experimental error, $2 \times \mathrm{Se}$, was 3.38. The absolute values of all coefficients are then lower than $2 \times \mathrm{Se}$. However, the main factors $\mathrm{x}_{4}$ and $\mathrm{x}_{5}$ and the interaction factor $\mathrm{x}_{1} \mathrm{x}_{3}$ can be selected as significantly effective on seed tuber formation.

Variety Florido seed tuber production. The computed coefficients of the effects of factors are presented in Table 5. The effects of the main and interaction factors were discriminated on Daniel diagram (Fig. 6). The experimental error of 2.696 was found then $2 \times \mathrm{Se}=5.39$. The absolute values of all coefficients are less than $2 \times$ Se and even less than Se. In this case and due to the dispersion from the Henry line (Fig. 6), the effects of the main factors $x_{1}, x_{2}$, $\mathrm{x}_{3}, \mathrm{x}_{4}$, and $\mathrm{x}_{5}$ are retained as significant.

Comparison of the treatments. Treatments of the fractional factorial plan (T1 to T8) were compared with the controls (TOS1 and TOS2). Regarding the survival rate, the analysis of variance for the two varieties showed no significant difference between the fractional factorial plan treatments and the TOS2 and T0S1 controls (P-values > 0.22). Concerning seed tubers production, the analysis of variance for the two varieties pointed out a highly significant difference between the PFF treatments and the TOS2 and TOS1 controls (P-values <0.001).

Optimisation results. From Table 6 of response optimisation conditions, DESIGNexpert software obtained 81 optimisation 
TABLE 2. Coefficients of the factors' effects on variety Bètè-bètè cuttings' survival rate

\begin{tabular}{|c|c|c|c|c|c|c|c|c|c|}
\hline $\begin{array}{l}\text { Assay } \\
\text { number }\end{array}$ & $\mathrm{x}_{0}$ & $\begin{array}{l}\text { Substrate } \\
\left(\mathrm{x}_{1}\right)\end{array}$ & $\begin{array}{l}\text { Cutting } \\
\text { sampling } \\
\text { level }\left(\mathrm{x}_{2}\right)\end{array}$ & $\begin{array}{l}\text { Cutting } \\
\text { sampling } \\
\text { stage }\left(\mathrm{x}_{3}\right)\end{array}$ & $\begin{array}{l}\text { Biostimulant } \\
\left(\mathrm{x}_{4}\right)\end{array}$ & $\begin{array}{l}\text { Fertiliser } \\
\left(\mathrm{x}_{5}\right)\end{array}$ & $\begin{array}{l}\text { Interaction } \\
\mathrm{x}_{1} \mathrm{x}_{3}\end{array}$ & $\begin{array}{l}\text { Interaction } \\
\mathrm{x}_{1} \mathrm{x}_{5}\end{array}$ & Response \\
\hline 1 & 1 & Humus soil & Median cutting & 120 das & $\begin{array}{l}\text { Coconut water } \\
5 \%\end{array}$ & Urea $2 \%$ & $\begin{array}{l}\text { Humus soil } \\
-120 \text { das }\end{array}$ & $\begin{array}{l}\text { Humus soil } \\
\text { - Urea } 2 \%\end{array}$ & 100 \\
\hline 2 & 1 & $\begin{array}{l}\text { Carbonised } \\
\text { rice husk }\end{array}$ & Median cutting & 120 das & $\begin{array}{l}\text { Coconut water } \\
10 \%\end{array}$ & Urea $2 \%$ & $\begin{array}{l}\text { Carbonised } \\
\text { rice husk - } 120 \text { das }\end{array}$ & $\begin{array}{l}\text { Carbonised } \\
\text { rice husk - Urea } 2 \%\end{array}$ & 90 \\
\hline 3 & 1 & Humus soil & Terminal cutting & 120 das & $\begin{array}{l}\text { Coconut water } \\
10 \%\end{array}$ & Urea 3\% & Humus soil - 120 das & Humus soil - Urea 3\% & 100 \\
\hline 4 & 1 & $\begin{array}{l}\text { Carbonised } \\
\text { rice husk }\end{array}$ & Terminal cutting & 120 das & $\begin{array}{l}\text { Coconut water } \\
5 \%\end{array}$ & Urea 3\% & $\begin{array}{l}\text { Carbonised rice husk } \\
-120 \text { das }\end{array}$ & $\begin{array}{l}\text { Carbonised rice husk } \\
\text { - Urea 3\% }\end{array}$ & 100 \\
\hline 5 & 1 & Humus soil & Median cutting & 90 das & $\begin{array}{l}\text { Coconut water } \\
5 \%\end{array}$ & Urea 3\% & Humus soil - 90 das & Humus soil - Urea 3\% & 0 \\
\hline 6 & 1 & $\begin{array}{l}\text { Carbonised } \\
\text { rice husk }\end{array}$ & Median cutting & 90 das & $\begin{array}{l}\text { Coconut water } \\
10 \%\end{array}$ & Urea 3\% & $\begin{array}{l}\text { Carbonised rice husk } \\
-90 \text { das }\end{array}$ & $\begin{array}{l}\text { Carbonised rice husk } \\
\text { - Urea 3\% }\end{array}$ & 20 \\
\hline 7 & 1 & Humus soil & Terminal cutting & 90 das & $\begin{array}{l}\text { Coconut water } \\
10 \%\end{array}$ & Urea $2 \%$ & Humus soil - 90 das & Humus soil - Urea $2 \%$ & 20 \\
\hline 8 & 1 & $\begin{array}{l}\text { Carbonised } \\
\text { rice husk }\end{array}$ & Terminal cutting & 90 das & $\begin{array}{l}\text { Coconut water } \\
5 \%\end{array}$ & Urea $2 \%$ & $\begin{array}{l}\text { Carbonised rice husk } \\
\text { - } 90 \text { das }\end{array}$ & $\begin{array}{l}\text { Carbonised rice husk } \\
\text { - Urea } 2 \%\end{array}$ & 40 \\
\hline Coefficients & a0 & a1 & a2 & a3 & a4 & a5 & a13 & a15 & \\
\hline Value & 58.75 & 3.75 & 6.25 & -38.75 & 1.25 & 3.75 & 6.25 & -1.25 & \\
\hline
\end{tabular}

$\mathrm{a} 0$ represents the mean response $\mathrm{x} 0$ at the centre of the experimental domain, when all factor levels are equal to $0 . \mathrm{x} 1$ : factor substrate with coefficient a1, $\mathrm{x} 2$ :factor sampling level of the cuttings with coefficient a2, $\mathrm{x} 3$ :factor sampling stage with coefficient $\mathrm{a} 3, \mathrm{x} 4=\mathrm{x} 1 \times 2$ :factor coconut water with coefficient a4, $\mathrm{x} 5=\mathrm{x} 2 \times 3$ :factor urea with coefficient a5,x1 3 :interaction factor of substrate and sampling stage with coefficient a45,x1x5:interaction factor of the substrate and urea with coefficient a34.+1:high level of the factor.-1:low level of the factor 


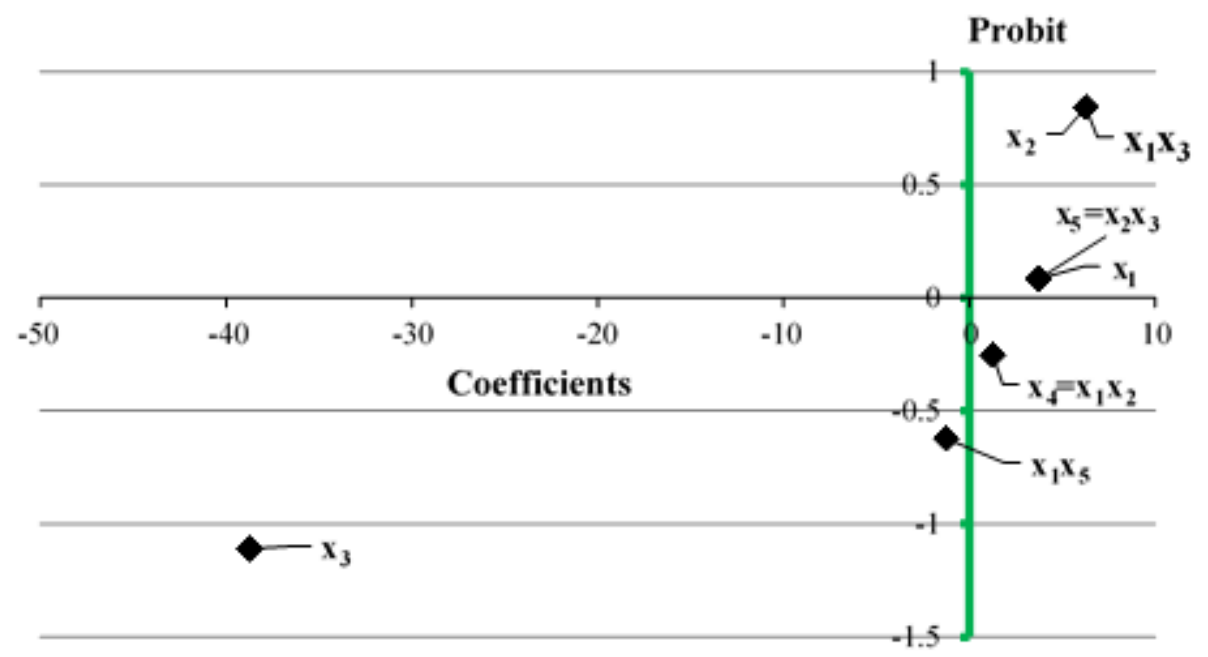

Fig ure 3. Daniel Diagram of main and interaction effects on Bètè-bètè cuttings's survival rate

Green $Y$-axis is the Henry line. $\mathrm{x}_{1}$ : factor substrate, $\mathrm{x}_{2:}$ factor sampling level of the cuttings, $\mathrm{x}_{3}$ : factor sampling stage $\mathrm{x}_{4}=\mathrm{x}_{1} \mathrm{x}_{2}$ : factor coconut water, $\mathrm{x}_{5}=\mathrm{x}_{2} \mathrm{x}_{3}$ : factor urea, $\mathrm{x}_{1} \mathrm{x}_{3}$ : interaction factor of substrate and sampling stage, $x_{1} x_{5}$ : interaction factor of the substrate and urea.

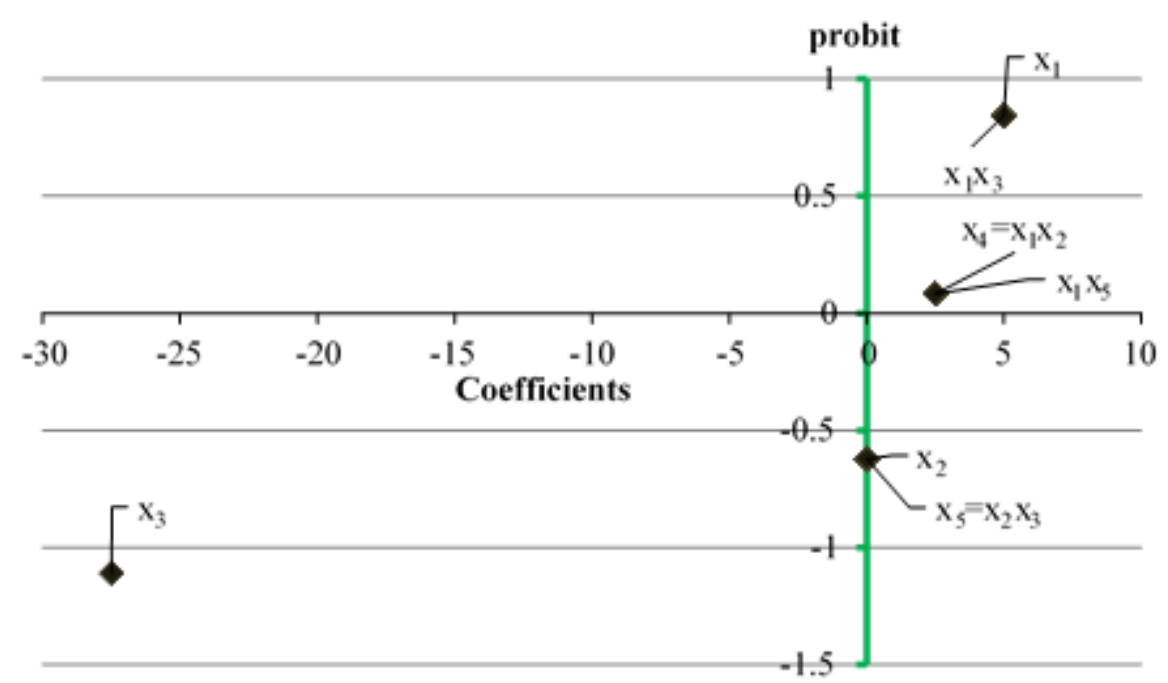

Figure 4. Daniel Diagram of main and interaction effects on Florido cuttings survival rate

Green $Y$-axis is the Henry line. $\mathrm{x}_{1}$ : factor substrate, $\mathrm{x}_{2:}$ factor sampling level of the cuttings, $\mathrm{x}_{3}$ : factor sampling stage $\mathrm{x}_{4}=\mathrm{x}_{1} \mathrm{x}_{2}$ : factor coconut water, $\mathrm{x}_{5}=\mathrm{x}_{2} \mathrm{x}_{3}$ : factor urea, $\mathrm{x}_{1} \mathrm{x}_{3}$ : interaction factor of substrate and sampling stage, $x_{1} x_{5}$ : interaction factor of the substrate and urea. 
TABLE 3. Coefficients of the factors' effects on variety Florido cuttings' survival rate

\begin{tabular}{|c|c|c|c|c|c|c|c|c|c|}
\hline $\begin{array}{l}\text { Assay } \\
\text { number }\end{array}$ & $\mathrm{x}_{0}$ & $\begin{array}{l}\text { Substrate } \\
\left(\mathrm{x}_{1}\right)\end{array}$ & $\begin{array}{l}\text { Cutting } \\
\text { sampling } \\
\text { level }\left(\mathrm{x}_{2}\right)\end{array}$ & $\begin{array}{l}\text { Cutting } \\
\text { sampling } \\
\text { stage }\left(\mathrm{x}_{3}\right)\end{array}$ & $\begin{array}{l}\text { Biostimulant } \\
\left(\mathrm{x}_{4}\right)\end{array}$ & $\begin{array}{l}\text { Fertiliser } \\
\left(\mathrm{x}_{5}\right)\end{array}$ & $\begin{array}{l}\text { Interaction } \\
\mathrm{x}_{1} \mathrm{x}_{3}\end{array}$ & $\begin{array}{l}\text { Interaction } \\
\mathrm{x}_{1} \mathrm{x}_{5}\end{array}$ & Response \\
\hline 1 & 1 & Humus soil & Median cutting & 120 das & $\begin{array}{l}\text { Coconut water } \\
5 \%\end{array}$ & Urea $2 \%$ & Humus soil - 120 das & $\begin{array}{l}\text { Humus soil } \\
\text { - Urea } 2 \%\end{array}$ & 100 \\
\hline 2 & 1 & $\begin{array}{l}\text { Carbonised } \\
\text { rice husk }\end{array}$ & Median cutting & 120 das & $\begin{array}{l}\text { Coconut water } \\
10 \%\end{array}$ & Urea $2 \%$ & $\begin{array}{l}\text { Carbonised rice husk } \\
-120 \text { das }\end{array}$ & $\begin{array}{l}\text { Carbonised rice husk } \\
\text { - Urea } 2 \%\end{array}$ & 100 \\
\hline 3 & 1 & Humus soil & Terminal cutting & 120 das & $\begin{array}{l}\text { Coconut water } \\
10 \%\end{array}$ & Urea 3\% & Humus soil - 120 das & Humus soil - Urea $3 \%$ & 100 \\
\hline 4 & 1 & $\begin{array}{l}\text { Carbonised } \\
\text { rice husk }\end{array}$ & Terminal cutting & 120 das & $\begin{array}{l}\text { Coconut water } \\
5 \%\end{array}$ & Urea $3 \%$ & $\begin{array}{l}\text { Carbonised rice husk } \\
-120 \text { das }\end{array}$ & $\begin{array}{l}\text { Carbonised rice husk - } \\
\text { Urea 3\% }\end{array}$ & 100 \\
\hline 5 & 1 & Humus soil & Median cutting & 90 das & Coconut water $5 \%$ & Urea 3\% & Humus soil - 90 das & Humus soil - Urea $3 \%$ & 40 \\
\hline 6 & 1 & $\begin{array}{l}\text { Carbonised } \\
\text { rice husk }\end{array}$ & Median cutting & 90 das & $\begin{array}{l}\text { Coconut water } \\
10 \%\end{array}$ & Urea $3 \%$ & $\begin{array}{l}\text { Carbonised rice husk } \\
-90 \text { das }\end{array}$ & $\begin{array}{l}\text { Carbonised rice husk } \\
\text { - Urea 3\% }\end{array}$ & 50 \\
\hline 7 & 1 & Humus soil & Terminal cutting & 90 das & $\begin{array}{l}\text { Coconut water } \\
10 \%\end{array}$ & Urea $2 \%$ & Humus soil - 90 das & Humus soil - Urea $2 \%$ & 30 \\
\hline 8 & 1 & $\begin{array}{l}\text { Carbonised } \\
\text { rice husk }\end{array}$ & Terminal cutting & 90 das & $\begin{array}{l}\text { Coconut water } \\
5 \%\end{array}$ & Urea $2 \%$ & $\begin{array}{l}\text { Carbonised rice husk } \\
\text { - } 90 \text { das }\end{array}$ & $\begin{array}{l}\text { Carbonised rice husk } \\
\text { - Urea } 2 \%\end{array}$ & 60 \\
\hline Coefficients & a0 & al & a2 & a3 & a4 & a5 & a13 & a15 & \\
\hline Value & 72.5 & 5 & 0 & -27.5 & 2.5 & 0 & 5 & 2.5 & \\
\hline
\end{tabular}

$\mathrm{a} 0$ represents the mean response $\mathrm{x} 0$ at the centre of the experimental domain, when all factor levels are equal to $0 . \mathrm{x} 1$ : factor substrate with coefficient a1, $\mathrm{x} 2$ :factor sampling level of the cuttings with coefficient $\mathrm{a} 2$, $\mathrm{x} 3$ :factor sampling stage with coefficient $\mathrm{a} 3, \mathrm{x} 4=\mathrm{x} 1 \mathrm{x} 2$ :factor coconut water with coefficient $\mathrm{a} 4$, $\mathrm{x} 5=\mathrm{x} 2 \mathrm{x} 3$ :factor urea with coefficient a5,x1x3:interaction factor of substrate and sampling stage with coefficient a45,x1x5:interaction factor of the substrate and urea with coefficient a34.+1:high level of the factor.-1:low level of the factor 
TABLE 4. Coefficients of the factors' effects on variety Bètè-bètè seed-tuber production

\begin{tabular}{|c|c|c|c|c|c|c|c|c|c|}
\hline $\begin{array}{l}\text { Assay } \\
\text { number }\end{array}$ & $\mathrm{x}_{0}$ & $\begin{array}{l}\text { Substrate } \\
\left(\mathrm{x}_{1}\right)\end{array}$ & $\begin{array}{l}\text { Cutting } \\
\text { sampling } \\
\text { level }\left(\mathrm{x}_{2}\right)\end{array}$ & $\begin{array}{l}\text { Cutting } \\
\text { sampling } \\
\text { stage }\left(\mathrm{x}_{3}\right)\end{array}$ & $\begin{array}{l}\text { Biostimulant } \\
\left(\mathrm{x}_{4}\right)\end{array}$ & $\begin{array}{l}\text { Fertiliser } \\
\left(\mathrm{x}_{5}\right)\end{array}$ & $\begin{array}{l}\text { Interaction } \\
\mathrm{x}_{1} \mathrm{x}_{3}\end{array}$ & $\begin{array}{l}\text { Interaction } \\
\mathrm{x}_{1} \mathrm{x}_{5}\end{array}$ & Response \\
\hline 1 & 1 & Humus soil & Median cutting & 120 das & $\begin{array}{l}\text { Coconut water } \\
5 \%\end{array}$ & Urea $2 \%$ & Humus soil - 120 das & Humus soil - Urea $2 \%$ & 10.10 \\
\hline 2 & 1 & $\begin{array}{l}\text { Carbonised } \\
\text { rice husk }\end{array}$ & Median cutting & 120 das & $\begin{array}{l}\text { Coconut water } \\
10 \%\end{array}$ & Urea $2 \%$ & $\begin{array}{l}\text { Carbonised rice husk } \\
-120 \text { das }\end{array}$ & $\begin{array}{l}\text { Carbonised rice husk } \\
\text { - Urea } 2 \%\end{array}$ & 0.00 \\
\hline 3 & 1 & Humus soil & Terminal cutting & 120 das & $\begin{array}{l}\text { Coconut water } \\
10 \%\end{array}$ & Urea 3\% & Humus soil - 120 das & Humus soil - Urea $3 \%$ & 0.00 \\
\hline 4 & 1 & $\begin{array}{l}\text { Carbonised } \\
\text { rice husk }\end{array}$ & Terminal cutting & 120 das & $\begin{array}{l}\text { Coconut water } \\
5 \%\end{array}$ & Urea 3\% & $\begin{array}{l}\text { Carbonised rice husk } \\
-120 \text { das }\end{array}$ & $\begin{array}{l}\text { Carbonised rice husk } \\
\text { - Urea 3\% }\end{array}$ & 0.00 \\
\hline 5 & 1 & Humus soil & Median cutting & 90 das & $\begin{array}{l}\text { Coconut water } \\
5 \%\end{array}$ & Urea 3\% & Humus soil - 90 das & Humus soil - Urea $3 \%$ & 0.00 \\
\hline 6 & 1 & $\begin{array}{l}\text { Carbonised } \\
\text { rice husk }\end{array}$ & Median cutting & 90 das & $\begin{array}{l}\text { Coconut water } \\
10 \%\end{array}$ & Urea 3\% & $\begin{array}{l}\text { Carbonised rice husk } \\
\text { - } 90 \text { das }\end{array}$ & $\begin{array}{l}\text { Carbonised rice husk } \\
\text { - Urea 3\% }\end{array}$ & 1.50 \\
\hline 7 & 1 & Humus soil & Terminal cutting & 90 das & $\begin{array}{l}\text { Coconut water } \\
10 \%\end{array}$ & Urea $2 \%$ & Humus soil - 90 das & Humus soil - Urea $2 \%$ & 0.36 \\
\hline 8 & 1 & $\begin{array}{l}\text { Carbonised } \\
\text { rice husk }\end{array}$ & Terminal cutting & 90 das & $\begin{array}{l}\text { Coconut water } \\
5 \%\end{array}$ & Urea $2 \%$ & $\begin{array}{l}\text { Carbonised rice husk } \\
-90 \text { das }\end{array}$ & $\begin{array}{l}\text { Carbonised rice husk } \\
\text { - Urea } 2 \%\end{array}$ & 8.58 \\
\hline Coefficients & $\mathrm{a} 0$ & a1 & a2 & a3 & a4 & a5 & a13 & a15 & \\
\hline Value & 2.56 & -0.04 & -0.33 & 0.04 & 2.10 & 2.19 & 2.47 & -0.42 & \\
\hline
\end{tabular}

$\mathrm{a} 0$ represents the mean response $\mathrm{x} 0$ at the centre of the experimental domain, when all factor levels are equal to $0 . \mathrm{x} 1$ :factor substrate with coefficient a1, $\mathrm{x} 2$ :factor sampling level of the cuttings with coefficient $\mathrm{a} 2$, $\mathrm{x} 3$ :factor sampling stage with coefficient $\mathrm{a} 3, \mathrm{x} 4=\mathrm{x} 1 \mathrm{x} 2$ :factor coconut water with coefficient $\mathrm{a} 4, \mathrm{x} 5=\mathrm{x} 2 \mathrm{x} 3$ :factor urea with coefficient a5,x1 3 :interaction factor of substrate and sampling stage with coefficient a45,x1x5:interaction factor of the substrate and urea with coefficient a34.+1:high level of the factor.-1:low level of the factor 


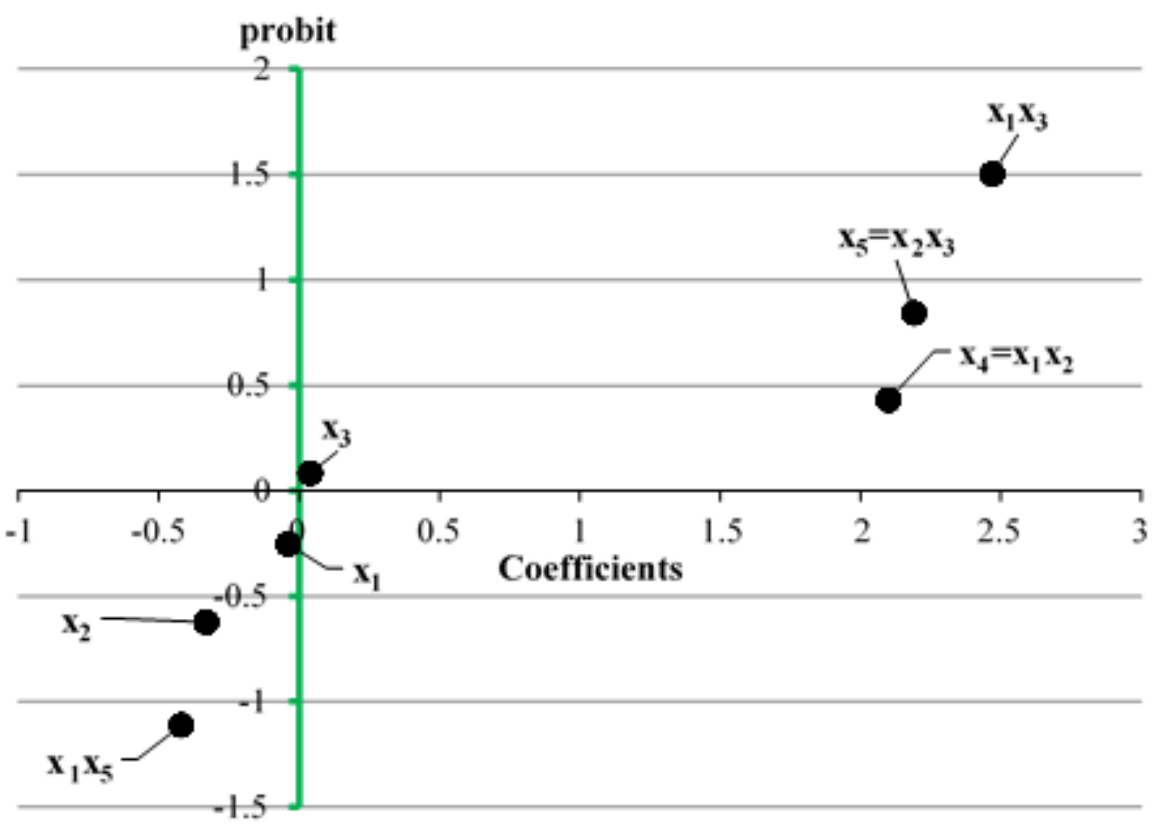

Figure 5. Daniel Diagram of main and interaction effects on Bètè-bètè seed-tuber production.

Green $Y$-axis is the Henry line. $\mathrm{x}_{1}$ : factor substrate, $\mathrm{x}_{2:}$ factor sampling level of the cuttings, $\mathrm{x}_{3}$ : factor sampling stage, $\mathrm{x}_{4}=\mathrm{x}_{1} \mathrm{x}_{2}$ : factor coconut water, $\mathrm{x}_{5}=\mathrm{x}_{2} \mathrm{x}_{3}$ : factor urea, $\mathrm{x}_{1} \mathrm{x}_{3}$ : interaction factor of substrate and sampling stage, $\mathrm{x}_{1} \mathrm{x}_{5}$ : interaction factor of the substrate and urea.

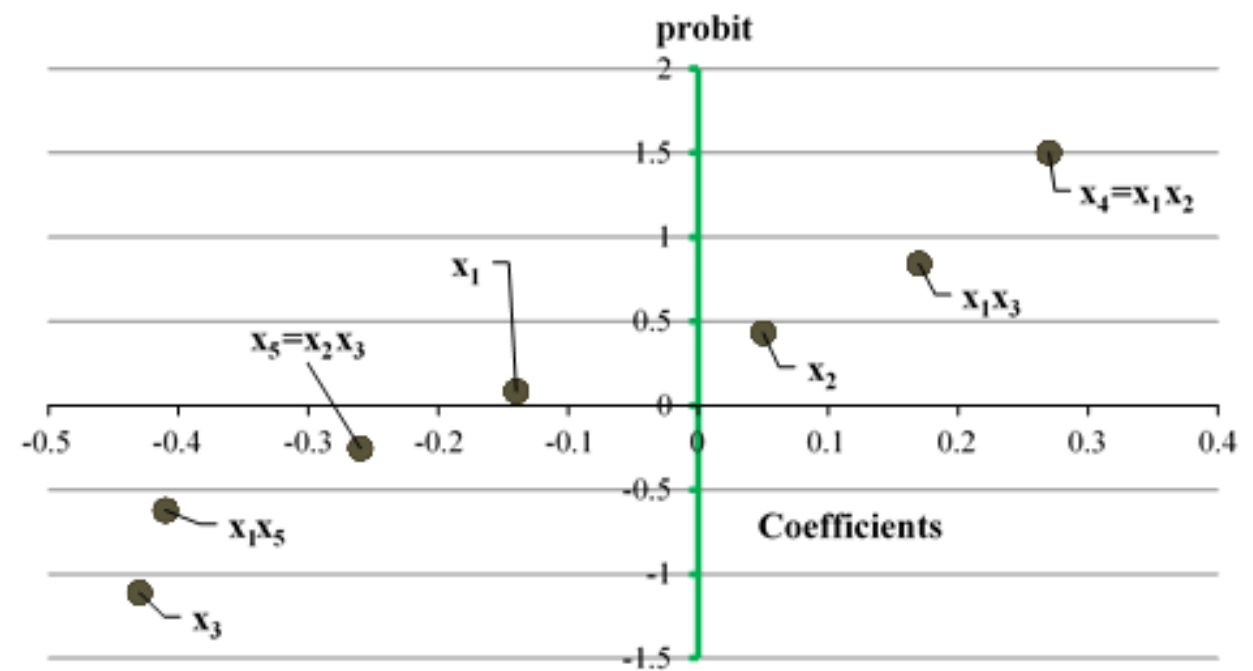

Figure 6. Daniel Diagram of main and interaction effects on Florido seed-tuber production

Green $Y$-axis is the Henry line. $x_{1}$ : factor substrate, $x_{2:}$ factor sampling level of the cuttings, $x_{3}$ : factor sampling stage, $\mathrm{x}_{4}=\mathrm{x}_{1} \mathrm{x}_{2}$ : factor coconut water, $\mathrm{x}_{5}=\mathrm{x}_{2} \mathrm{x}_{3}$ : factor urea, $\mathrm{x}_{1} \mathrm{x}_{3}$ : interaction factor of substrate and sampling stage, $\mathrm{x}_{1} \mathrm{x}_{5}$ : interaction factor of the substrate and urea. 
TABLE 5. Coefficients of the factors' effects on variety Florido seed-tuber production

\begin{tabular}{|c|c|c|c|c|c|c|c|c|c|}
\hline $\begin{array}{l}\text { Assay } \\
\text { number }\end{array}$ & $\mathrm{x}_{0}$ & $\begin{array}{l}\text { Substrate } \\
\left(\mathrm{x}_{1}\right)\end{array}$ & $\begin{array}{l}\text { Cutting } \\
\text { sampling } \\
\text { level }\left(\mathrm{x}_{2}\right)\end{array}$ & $\begin{array}{l}\text { Cutting } \\
\text { sampling } \\
\text { stage }\left(\mathrm{x}_{3}\right)\end{array}$ & $\begin{array}{l}\text { Biostimulant } \\
\left(\mathrm{x}_{4}\right)\end{array}$ & $\begin{array}{l}\text { Fertiliser } \\
\left(\mathrm{x}_{5}\right)\end{array}$ & $\begin{array}{l}\text { Interaction } \\
\mathrm{x}_{1} \mathrm{x}_{3}\end{array}$ & $\begin{array}{l}\text { Interaction } \\
\mathrm{x}_{1} \mathrm{x}_{5}\end{array}$ & Response \\
\hline 1 & 1 & Humus soil & Median cutting & 120 das & $\begin{array}{l}\text { Coconut water } \\
5 \%\end{array}$ & Urea $2 \%$ & Humus soil - 120 das & Humus soil - Urea $2 \%$ & 1.99 \\
\hline 2 & 1 & $\begin{array}{l}\text { Carbonised } \\
\text { rice husk }\end{array}$ & Median cutting & 120 das & $\begin{array}{l}\text { Coconut water } \\
10 \%\end{array}$ & Urea $2 \%$ & $\begin{array}{l}\text { Carbonised rice husk } \\
-120 \text { das }\end{array}$ & $\begin{array}{l}\text { Carbonised rice husk } \\
\text { - Urea } 2 \%\end{array}$ & 0 \\
\hline 3 & 1 & Humus soil & Terminal cutting & 120 das & $\begin{array}{l}\text { Coconut water } \\
10 \%\end{array}$ & Urea $3 \%$ & Humus soil - 120 das & Humus soil - Urea $3 \%$ & 1.26 \\
\hline 4 & 1 & $\begin{array}{l}\text { Carbonised } \\
\text { rice husk }\end{array}$ & Terminal cutting & 120 das & $\begin{array}{l}\text { Coconut water } \\
5 \%\end{array}$ & Urea $3 \%$ & $\begin{array}{l}\text { Carbonised rice husk } \\
-120 \text { das }\end{array}$ & $\begin{array}{l}\text { Carbonised rice husk } \\
\text { - Urea 3\% }\end{array}$ & 2 \\
\hline 5 & 1 & Humus soil & Median cutting & 90 das & $\begin{array}{l}\text { Coconut water } \\
5 \%\end{array}$ & Urea $3 \%$ & Humus soil - 90 das & Humus soil - Urea $3 \%$ & 0.49 \\
\hline 6 & 1 & $\begin{array}{l}\text { Carbonised } \\
\text { rice husk }\end{array}$ & Median cutting & 90 das & $\begin{array}{l}\text { Coconut water } \\
10 \%\end{array}$ & Urea $3 \%$ & $\begin{array}{l}\text { Carbonised rice husk } \\
\text { - } 90 \text { das }\end{array}$ & $\begin{array}{l}\text { Carbonised rice husk } \\
\text { - Urea } 3 \%\end{array}$ & 0.84 \\
\hline 7 & 1 & Humus soil & Terminal cutting & 90 das & $\begin{array}{l}\text { Coconut water } \\
10 \%\end{array}$ & Urea $2 \%$ & Humus soil - 90 das & Humus soil - Urea $2 \%$ & 0.35 \\
\hline 8 & 1 & $\begin{array}{l}\text { Carbonised } \\
\text { rice husk }\end{array}$ & Terminal cutting & 90 das & $\begin{array}{l}\text { Coconut water } \\
5 \%\end{array}$ & Urea $2 \%$ & $\begin{array}{l}\text { Carbonised rice husk } \\
\text { - } 90 \text { das }\end{array}$ & $\begin{array}{l}\text { Carbonised rice husk } \\
\text { - Urea } 2 \%\end{array}$ & 0.13 \\
\hline Coefficients & $\mathrm{a} 0$ & a1 & $\mathrm{a} 2$ & a3 & $\mathrm{a} 4$ & a5 & a13 & a15 & \\
\hline Value & 0.88 & -0.14 & 0.05 & -0.43 & 0.27 & -0.26 & 0.17 & -0.41 & \\
\hline
\end{tabular}

$\mathrm{a} 0$ represents the mean response $\mathrm{x} 0$ at the centre of the experimental domain, when all factor levels are equal to $0 . \mathrm{x} 1$ :factor substrate with coefficient a1, $\mathrm{x} 2$ :factor sampling level of the cuttings with coefficient $\mathrm{a} 2$, $\mathrm{x} 3$ :factor sampling stage with coefficient $\mathrm{a} 3, \mathrm{x} 4=\mathrm{x} 1 \mathrm{x} 2$ :factor coconut water with coefficient $\mathrm{a} 4, \mathrm{x} 5=\mathrm{x} 2 \mathrm{x} 3$ :factor urea with coefficient a5,x 1 3 :interaction factor of substrate and sampling stage with coefficient a45,x1x5:interaction factor of the substrate and urea with coefficient a34.+1:high level of the factor.-1:low level of the factor 
TABLE 6. Factors affecting the survival rate and the seed-tuber's production of varieties Bètè-bètè (Txsbb-Prodbb) and Florido (Txsflo-prodflo) in central region of Côte d'Ivoire

\begin{tabular}{llccccc}
\hline Responses & Objective & Lower limit & Upper limit & Lowest rate & Highest rate & Importance \\
\hline Txsbb & Maximise & 0 & 100 & 0.1 & 1 & 3 \\
Prodbb & Maximise & 0 & 10.1 & 0.1 & 1 & 5 \\
Txsflo & Maximise & 30 & 100 & 0.1 & 1 & 3 \\
Prodflo & Maximise & 0 & 2 & 0.1 & 1 & 5 \\
\hline
\end{tabular}

responses ranked in decreasing order of importance. Then the software selected the best result presented in Table 7 . Thus, the optimal treatment for the 2 varieties is humus soil as substrate moistured with urea $2 \%$, the median stem-cutting sampled at 90 days after sowing, and soaked in $5 \%$ coconut water solution.

\section{DISCUSSION}

Stem-cuttings' survival rate. The influence of the sampling stage $\mathrm{x}_{3}$ (120 and 90 days after sowing) with a coefficient of -38.75 , and the sampling level $\mathrm{x}_{2}$ (median cutting and terminal cutting) with a coefficient of 6.25 on the survival rate of stem cuttings of the Bètèbèté variety on a one hand and that of the sampling stage $\mathrm{x}_{3}$ with a coefficient of -27.5 for the Florido variety demonstrate that it is necessary to use shoots during the active growing phase. The same observation was made in our previous work where we used 90 and 120 days after sowing stem cuttings with survival rates of $72 \%, 64 \%, 97 \%$ and $96 \%$ for the varieties Kponan, Krenglè, C18 and C140 respectively; C18 and C140 being varieties of the alata species (Dibi et al., 2014).

The formation of young shoots is one of the development phases of yam stems as indicated by Rodrýìguez-Montero et al. (2001), which corresponds to the period of exponential growth of the aerial part resulting in accumulation of dry matter. During this phase, the plant builds these two poles, namely the "source" which is the aerial part and the "sink" which is the storage organ (the tuber). The substrate $\mathrm{x}_{1}$ (humus soil and Carbonised rice husk) also had a significant effect on the survival rate of stem cuttings for both varieties. These results are consistent with those of Acha et al. (2004) and Kikuno et al. (2006), who concluded that only carbonised rice husk seem to promote rooting and germination of stem cuttings, which are essential for their survival.

The substrate also has a significant effect on the survival rate of stem cuttings with coefficients of 3.75 and 5 respectively for the varieties Bètè-bètè and Florido. Humus soil and carbonised rice husks have practically the same response values (for the Bètè-bètè variety, $2 \times 100 \%$ for humus soil, $90 \%$ and $100 \%$ for carbonised rice husks; $2 \times 100 \%$ for humus soil and carbonised rice husks at the Florido variety). The importance of carbonised rice husks has been noted by Acha et al., (2004) and Kikuno et al., (2009), who have obtained good results with this substrate which seems to promote the rooting and germination of stem cuttings. Based on the results of our study, humus soil can be retained as a substrate as long as it is well decomposed. This result is also consistent with the result obtained by the Design-expert software.

Seed-tubers' production. For the variety Bètè-bètè, $\mathrm{T} 1$ and $\mathrm{T} 8$ treatments obtained an average production of $10.09 \mathrm{~g}$ and $8.58 \mathrm{~g}$ respectively. For these treatments, coconut water and urea have the most significant effects with coefficients of 2.1 and 2.19 respectively. For the Florido variety, T1 and T3 treatments have an average production of 1.99 and 1.26 
I.K. FOFANA et al.

g respectively. It was also noted that coconut water and urea had the most significant effects (0.27 and -0.26 , respectively).

It can, therefore, be inferred that these two factors better optimise the average weight parameter of minitubers. For these treatments, coconut water $\mathrm{x}_{4}$ and urea $\mathrm{x}_{5}$ had the most significant effects with coefficients of 2.1 and 2.19 , respectively. The effect of coconut water was demonstrated by Agele et al. (2010). Indeed, stem cuttings of cultivar TDr 93-49 immersed in 5\% coconut water solution gave the highest number of minitubers (1.9), compared to the untreated control (0.5) (Agele et al., 2010).

Akuailu and co-workers (2006) studied the yeast microflora of coconut water from two Ivorian varieties. They concluded that the microbiological value of this water was satisfactory for its use as a culture medium. Assa and co-workers (2007) analysed the water of two coconut hybrids. They highlighted the presence of ash $(0.49 \%)$, sugars (29.37 and 28.09\%) and polyphenols (58.11 and $65.49 \mathrm{ppm}$ ), making it an appropriate culture medium.

Many experiments on the chemical composition of coconut water have shown that it contains phytohormones, in particular cytokinin, which has a stimulating effect on metabolism and promotes caulogenesis (Lazin et al., 2015). Yong and co-workers (2009) found the presence of cytokinins, auxin in the indole-3-acetic acid (IAA) form, gibberellin and various inorganic ions. This particular composition of coconut water justifies its use as a growth supplement in the cultivation and micro-propagation of plant tissues.

Regarding the effects of urea, Behera et $a l$. (2009) showed that the treatment of $D$. alata $\mathrm{L}$. stem cuttings with a $2 \%$ concentration resulted in a higher number of mini-tubers (1.84 with an average weight of $1.98 \mathrm{~g}$ ), compared to the untreated control which yielded 0.78 mini-tuber with an average weight of $1.84 \mathrm{~g}$. As in the case of variety Bètè-bètè, coconut water and urea also had a positive influence in Florido seed-tuber production. 
Treatments comparison. The absence of significant difference between PFF treatments and controls for survival rates would mean that this parameter is not influenced by stimulation agent 1 (coconut water) and 2 (urea) which were removed from the control treatments. Stem cuttings would express their potential according to their morphogenetic characteristics and environmental conditions. However, for seed tuber production, the highly significant difference between treatments would mean that these stimulation agents influence this parameter. They would act as inhibitors either individually or in combination.

\section{CONCLUSION}

One of the objectives of this study, which was to improve the yam seed-tubers producing technique from aerial stem cuttings, has been partially achieved. Indeed, the factors that increase the production have been identified. The importance and the contribution of the selected factors were highlighted through the evaluation of their effects which can be expressed in a mathematical model based on the computation of the coefficients of each of the parameters. At this point of the study, three factors, namely the substrate (humus soil), the stem-cuttings sampling level (median stem cutting) and the growth stage (90 das) at which the stem cuttings are taken from the field, appear to be the critical factors that guarantee a good survival rate of stem-cuttings. For seedtuber's production, coconut water dilued at $5 \%$ and urea solution diluted at $2 \%$ are the most influential parameters.

\section{ACKNOWLEDGEMENT}

The authors are grateful to the team of the "Programme Plantes à Racines et Tubercules" of the Centre National de Recherches Agronomiques (CNRA), and Doctor Dao Daouda from Centre Suisse de Recherche Scientifique (CSRS) for their material and technical support.

\section{REFERENCES}

Acha, I.A., Shiwachi, H., Asiedu, R. and Akoroda, M.O. 2004. Effect of auxins on root development in yam (Dioscorea rotundata) vine. Tropical Science 44(2): 80-84.

Agele, S.O., Ayankanmi, T.G. and Kikuno, H. 2010. Effects of synthetic hormone substitutes and genotypes on rooting and mini tuber production of vines cuttings obtained from white yam (Dioscorea rotundata, Poir). African Journal of Biotechnology 9(30):4714-4724.

Akoroda, M.O. and Okonmah, L.U. 1982. Sett production and germoplasm maintenance through vine cuttings in yams. Tropical Agriculture 59(30):311-314.

Akuailou, E. N., Kouamé, D. and Biego, H.G. 2006. Etude de la microflore lévurienne de l'eau de coco mature (Cocos nucifera) des variétés Grand Ouest Africain et Port Bouet 121. Cahier de Santé Publique. vol. 5. $\mathrm{n}^{\circ} 1$ EDUCI.

Assa, R.R., Konan, J.L., Agbo, N., Prades, A. and Nemlin, J. 2007. Caractéristiques physico-chimiques de l'eau des fruits de quatre cultivars de cocotier (Cocos nucifera L.) en Côte d'Ivoire. Agronomie Africaine 19 (1): 41-51

Ayankanmi, T.G. and Agele, S.O. 2010. Effects of genotype, root- promoting substances and planting media on yam (Dioscorea rotundata Poir.) vine cuttings for mini tuber production. Advances in Environmental Biology 4(3):353-359.

Behera, K.K., Debashrita, P., Sahoo, S., Maharana, T. and Sethi, B.K. 2009. Effect of GA3 and urea treatments on improvement of microtuber production and productivity of different types of planting material in greater yam (Dioscorea alata L.). Notulae Botanicae Horticulturae Agrobotanici Cluj-Napoca 37(2):81-84.

Buffard-Morel, J. and Toure, B. 1980. Multiplication végétative par bouturage de cultivars appartenant au complexe 
Dioscorea cayenensis- D. rotundata. Laboratoire de botanique - ORSTOM, Laboratoire de génétique : département de biologie végétale. Faculté des sciences. Annales Université Abidjan-série C (sciences) tome XVI-1980.

Coyne D., Tchabi A., Bainey H. and Labuschagne N. 2006. Distribution and prevalence of nematodes (Scutellonema bradys and Meloidogyne spp.) on matketin yam (Dioscorea spp) in wewt Africa. Field Crop Research 96:142-150.

Dagnelie, P. 2008. Expérimentation agronomique et expérimentation industrielle. Journal des ingénieurs 110: 26-30.

Dansi, A. 2003. Les variétés d'ignames cultivées: Savoir-faire paysan au Bénin. Food \& Agriculture Org.

Dibi, K., Kouakou, A.M., Yéo, T.J., Fofana, I.K., N'zué, B. and Brou, Y.C. 2014. Effects of planting modes on yam (Dioscorea rotundata, Poir, and Dioscorea alata L.) vine cuttings for mini tubers production. International Journal of Sciences 3(11):1-8. https://www.ijsciences. com/pub/article/578 7 November 2018.

FAOSTAT. 2017. FAO Crop Production Data [WWW Document]. URL http//faostat.fao. org/ (Accessed 9.7.17).

Feinberg, M. 1996. Le criblage des facteurs. In: Feinberg, M. (Eds.), La validation des méthodes d'analyse: Une approche chimiométrique de l'assurance qualité au laboratoire. pp. 218-281. Masson Paris, France.

Foua-Bi, K. 1993. Les altérations post-récoltes des fruits, des tubercules, rhizomes et racines. Atelier sur les problèmes de stockage des fruits, tubercules et autres denrées périssables tenu à Yamoussoukro du 22 au 26 septembre 1993.

Hinvi, J.C. and Nonfon, R. 2000. La production et la commercialisation des semenceaux d'igname à Ouaké: Une nécessité de plus en plus incontournable. Ebert, A.W. and Djinadou, K. (Eds.),
L'igname et la pomme de terre en Afrique de l'Ouest. Actes de l'atelier sous régional sur l'igname et la pomme de terre, INA, Bénin: 7-8.

Jayaraman, K. 1999. Plan et analyse d'expérience. In: Jayaraman, K. (Ed.), Manuel de statistique pour la recherche forestière. pp. 70-141. Kerala Forest Research Institute archives de documents de FAO.

Kikuno, H., Muamba, K., Shiwachi, H., Micho, O. and Asiedu, R. 2006. Mini tuber production of white yam $(D$. rotundata) using vines. Japanese Journal of Tropical Agriculture 50: 1-3.

Lazim, M.I.M., Badruzaman, N.A., Peng, K.S. and Long, K. 2015. Quantification of cytokinins in coconut water from different maturation stages of Malaysia's coconut (Cocos nucifera L.) varieties. J Food Process Technol 6. 515 doi: 10.4172/21577110.1000515.

Morineau A. and Chatelin, Y-M. 2005. L'analyse statistique des données: Apprendre, comprendre et réaliser avec Excel : cours et exercices. Ellipses. Edition Marketing S.A. pp. 323-343.

Phillips, I.D.J. 1971. The biochimistry and physiology of plant growth, MC GRAWHill Book Company, New York, USA. 71: 124-126.

Plant, A. 2013. Be sure to check the residuals when analyzing the outcome of your designed experiments. SQT blog, April 30, 2013.

Preston, J.W.H. and Haun, J.R. 1962. Factors involved in the vegetative propagation of Dioscorea spiculiflora Hems. from vines. Proceedings of the American Society for Horticultural Science pp. 417-429.

Rodrýìguez-Montero, W., Hilger, T.H. and Leihner, D.E. 2001. Effects of seed rates and plant populations on canopy dynamics and yield in the greater yam (Dioscorea alata L.). Field Crops Research 70(1):1526. 
Sylla, K. 2009. Production de l'igname et Yates, F. 1978. The design and analysis of environnement socio-économique. Agronomie Africaine 4:177-185. factorial experiments. Harpenden, Imperial Bureau of Soil Science. 95pp.

Yates, F. 1935. Complex experiments. Yong, J.W.H., Ge, L., Ng, Y.F. and Tan, S.N. Supplement to the Journal of the Royal 2009. The chemical composition and Statistical Society 2(2):181-247. biological properties of coconut (Cocos nucifera L.) water. Molecules 14:51445164; doi: 10.3390/molecules 14125144. 